\title{
Effects of carprofen administered by different routes to control experimental uveitis in dogs
}

[Efeitos do carprofeno, aplicado por diferentes vias, no controle de uveítes experimentais em cães]

\author{
A.P. Ribeiro ${ }^{1}$, A. Escobar ${ }^{1}$, T.F. Motheo ${ }^{1}$, C.A.M. Sakamoto ${ }^{1}$, \\ G.S. Godoy ${ }^{1}$ M.A.N. Costa ${ }^{2}$, J.L. Laus ${ }^{3 *}$ \\ ${ }^{1}$ Aluno de pós-graduação - FCAV-UNESP - Jaboticabal, SP \\ ${ }^{2}$ Médico autônomo \\ ${ }^{3}$ Faculdade de Ciências Agrárias e Veterinárias - UNESP \\ Via de Acesso Professor Paulo Donato Castellane, s/n \\ 14884-900 - Jaboticabal, SP
}

\begin{abstract}
Efficacy of carprofen, administered by different routes, was studied in experimental uveitis in dogs. Anterior chamber paracenteses was accomplished at two different moments (M0 and M1), with a five hour interval between them. At M0 and M1, $0.2 \mathrm{~mL}$ of aqueous humor was collected and quantitation of total protein and prostaglandin $\mathrm{E}_{2}\left(\mathrm{PGE}_{2}\right)$ were determined. Four groups were formed $(\mathrm{n}=8)$, which received carprofen at the end of M0, by the following routes: subcutaneous (GIm), subconjunctival (GII), and topical (GIII). A fourth group that received no treatment was instituted (Control). Conjunctival histopathology of the GII animals was performed. In all groups, values of protein and PGE $_{2}$ significantly enhanced at M1; however, they did not significantly change among groups at M1. Inflammatory exudate of acute character and mild hemorrhage were seen at histopathology after carprofen administration. Carprofen was unable to inhibit $\mathrm{PGE}_{2}$ synthesis and the protein influx to the anterior chamber by any of the tested routes. However, the reduction of $44 \%$ in protein levels (topical) suggests that the agent can be used by this route as an adjuvant to control uveitis in dogs.
\end{abstract}

Keywords: dog, uveitis, carprofen, total protein, prostaglandin $\mathrm{E}_{2}$

\section{RESUMO}

Estudaram-se os efeitos do carprofeno, aplicado por diferentes vias, em uveítes experimentais em cães. Realizou-se paracentese de câmara anterior em dois momentos (M0 e M1), com intervalo de cinco horas entre si. Em MO e M1, colheram-se 0,2mL de humor aquoso e determinaram-se as concentrações de proteína total e de prostaglandina $E_{2}\left(P G E_{2}\right)$. Constituíram-se quatro grupos $(n=8)$, que receberam carprofeno ao final de M0 pelas vias subcutânea (GI), subconjuntival (GII) e tópica (GIII). Um quarto grupo não recebeu tratamento (controle). Procedeu-se à avaliação histopatológica nos indivíduos do GII. Em todos os grupos, encontrou-se aumento significativo dos níveis proteicos e de PGE $E_{2}$ em M1. Não se observou diferença significativa, em M1, entre os grupos para nenhum dos parâmetros estudados. Exsudado inflamatório de caráter agudo e hemorragia discreta foram vistos à histopatologia após a aplicação do fármaco. O carprofeno foi ineficaz em inibir a síntese de $P_{G} E_{2}$ e o influxo de proteínas para a câmara anterior, por qualquer uma das vias testadas. Contudo, a redução de $44 \%$ nos níveis de proteínas (via tópica), sugere que por esta via ele pode ser utilizado como adjuvante no controle da uveíte em cães.

Palavras chave: cão, uveíte, carprofeno, proteína total, prostaglandina $E_{2}$

Recebido em 28 de janeiro de 2009

Aceito em 31 de março de 2010

* Autor para correspondência (corresponding author)

E-mail: jllaus@fcav.unesp.br 


\section{INTRODUCTION}

Anterior uveitis is defined as the inflammation of the iris and ciliary body. The condition courses with most of the intraocular diseases, due to the highly vascular nature of uvea and its contiguity with other structures of the eye (Collins and Moore, 1999). Numerous infectious and noninfectious diseases can cause anterior uveitis (van der Woerdt, 2001).

The anterior segment of the eye has a selective barrier (blood-aqueous barrier), which controls the flux between the blood current and the primary aqueous humor (Gum et al., 1999). The integrity of the blood-aqueous barrier depends on tight junctions, located at the nonpigmented epithelium of the ciliary body, which controls the influx of aqueous fluid to the posterior chamber. This barrier is disrupted in anterior uveitis, resulting in the exudation of plasma proteins and cellular components into the anterior chamber, what can be clinically detected as aqueous flare. Such events are responsible for secondary aqueous humor formation.

Several chemical mediators have been studied regarding the canine uveitis pathogenesis, such as histamine, leukotrienes $B_{4}$ and $D_{4}$, reactive oxygen metabolites, and the tumor necrosis factor (Ward et al., 1992; Collins and Moore, 1999; Pinard et al., 2006). Notwithstanding, none of these seemed to play an important role upon the integrity of the blood-aqueous barrier after experimentally induced-uveitis in dogs (Diziezyc et al., 1992; Collins and Moore, 1999; Gilmour and Lehenbauer, 2006; Pinard et al., 2006). In this context, prostaglandins (PGs) are considered the most important chemical mediators of intraocular inflammation (Diziezyc et al., 1992; Rose et al., 1996; Collins and Moore, 1999; Gilmour and Lehenbauer, 2006; Pinard et al., 2006).

Uveitis are managed by topical instillation of mydriatics and cycloplegics associated with topically and systemically administration steroidal and/or nonsteroidal antiinflammatory drugs, associated with the treatment of the underlying disease (van der Woerdt, 2001). Fibrinolytics agents may be useful when blood clots and cellular debris are present (Gelatt and Gelatt, 2001). Subconjunctival administration of antiinflammatory drugs is an alternative route when markedly inflammation is present, once this route delivers higher levels of medication to the eye for an extended period of time (Holmberg and Maggs, 2004).

Nonsteroidal antiinflammatory drugs (NSAIDs) should be considered in uveitis (Ward, 1996; Krohne et al., 1998a; Giuliano, 2004; Gilmour and Lehenbauer, 2006; Pinard et al., 2006). Their use is preferable upon corticosteroids in diabetic animals and in those with systemic diseases (Massa et al., 2002). In addition, NSAIDs are recommended due to their ability to prevent miosis formation (Krohne et al., 1998a; Gelatt and Gelatt, 2001).

Carprofen is a nonnarcotic NSAID with a moderate potential to inhibit phospholipase $\mathrm{A}_{2}$. It is a reversible inhibitor of cyclooxygenases (Clark et al., 2003) with a higher selectivity to the cyclooxygenase-2 (Brideau et al., 2001; Streppa et al., 2002).

Krohne et al. (1998b) reported that carprofen had been shown to reduce the inflammatory response in a pilocarpine induced-uveitis experimental model by $68 \%$, when orally administered in dogs. The efficacy of the agent was confirmed in diminishing the levels of $\mathrm{PGE}_{2}$ in aqueous humor in dogs that underwent experimental paracentesis (Pinard et al., 2006).

Due to the antiinflammatory efficacy of carprofen in distinct tissues, this study was carried out to evaluate its effects in the scope of the ophthalmology, by topical and subconjunctival routes, once both of them have not yet been tested. These routes were compared to the subcutaneous route by $\mathrm{PGE}_{2}$ and protein quantitation in the aqueous humor after experimental paracentesis in dogs. Additionally, conjunctival histopathology was performed in order to investigate occasional intercurrences related to its safety and adverse effects.

\section{MATERIAL AND METHODS}

This study was approved by the Ethics Committee on Animal Experimentation at the Faculdade de Ciências Agrárias e Veterinárias at the Universidade do Estado de São Paulo (Protocol $\mathrm{n}^{\mathrm{o}}$ 011964-06), and followed the ethical norms established by the Association for 
Research in Vision and Ophthalmology (National Institutes of Health, Publications no. 85-23, revised 1985).

Twenty poodles and 12 mongrel dogs, clinically healthy, averaging $12 \mathrm{~kg}$, and aging from 11 to 14-month-old were used. All subjects were submitted to a complete physical and ophthalmic - Schirmer tear test (Ophthalmos, São Paulo, Brazil), biomicroscopy (Portable SL 14, Kowa, Japan), tonometry (Tonopen XL-Mentor O\&O, Norwell), indirect opthalmoscopy (Binocular indirect ophtalmoscope OHC-Eye Tec, São Carlos, Brazil), and fluorescein staining (Ophthalmos) - examination in order to exclude systemic and ophthalmic abnormalities. Once selected, dogs were housed in individual kennels, fed a dry pellet (Royal Canin, Descalvado, Brazil) twice daily and water $a d$ libitum, vaccinated (Duramune Max-Fort Dodge, Campinas, Brazil), and dewormed (Ivermectin-Ouro Fino, Ribeirão Preto, Brazil).

In order to promote blood-aqueous barrier breakdown and to collect $0.2 \mathrm{~mL}$ of primary aqueous humor (M0), all dogs underwent general anesthesia by a bolus dose of propofol (Diprivan-Cristália, São Carlos, Brazil) $(10 \mathrm{mg} / \mathrm{kg})$, and anterior chamber paracentesis of the left eye was accomplished as previously described by Ward et al. (1991). Five hours latter (M1), another paracentesis was performed to obtain $0.2 \mathrm{~mL}$ of secondary aqueous humor.

Primary and secondary aqueous samples of each dog were transferred to Eppendorf microtubes $(0.1 \mathrm{~mL}$ in each). Both microtubes were identified and centrifugated for five minutes at $3,500 \mathrm{rpm}$; one of them was refrigerated at $5^{\circ} \mathrm{C}$ for total protein quantitation (Sensiprot-Labtest, Lagoa Santa, Brazil), one hour after collection, and the other one was frozen at $-70^{\circ} \mathrm{C}$ for further prostaglandin $\mathrm{E}_{2}$ quantitation (EIA kit-Cayman Chemical, Ann Arbor, USA).

Four groups $(n=8)$ were formed. Group I (GI) animals were treated with $4.4 \mathrm{mg} / \mathrm{kg}$ subcutaneous carprofen (Rimadyl-Pfizer Saúde Animal, Guarulhos, Brazil); group II (GII) dogs received $2.2 \mathrm{mg} / \mathrm{kg}$ of the same drug in the dorsolateral aspect of the bulbar conjunctival of the left eye, not exciding a final volume of $0.2 \mathrm{~mL}$. The commercial formulation was diluted in sterile water (1:3), to obtain a final solution of $0.5 \%$ to be used in a third group (GIII) of animals, which received one drop on the cornea of the left eye. A control group was formed and received no treatment. Literature recommends that when the topical route is instituted for management of uveitis, antiinflammatory drugs should be instilled several times per day (Collins and Moore, 1999; van der Woerdt, 2001). For this reason, only the GIII animals were treated by the end of M0, and subsequently, hourly until M1.

Aqueous humor samples obtained at both moments were diluted from proportion of 1:5 to $1: 10$, and kept in water bath at $37^{\circ} \mathrm{C}$, for 15 minutes. Protein quantitation was performed with a commercial chemistry analyzer. The results were expressed in milligram per deciliter $(\mathrm{mg} / \mathrm{dL})$.

For Prostaglandin $\mathrm{E}_{2}\left(\mathrm{PGE}_{2}\right)$ quantitation, all samples obtained at M0 and M1 were submitted to a competitive enzyme immunoassay. Samples were thawed at room temperature, diluted from proportion of $1: 10$ to $1: 40$ in Milli $Q$ water. Results obtained in absorbance unities were transformed to picograms per microliters $(\mathrm{pg} / \mathrm{mL})$ by a specific software (Cayman Chemical).

Twenty-four hours after M1, one drop of tetracaine/fenilefrin (Allergan, Guarulhos, Brazil) was topically applied and a conjunctival specimen was collected near by the site where carprofen was injected in the animals of GII. Obeying the same criteria, a specimen of the left eye of the control animals was collected.

Biopsied eyes received ophthalmic ointment with chloramphenicol, vitamin $\mathrm{A}$, and aminoacids $^{13}$ after the procedure, every each eight hours, for five consecutive days. Conjunctival specimens were fixed in $10 \%$ formalin, stained with Hematoxilin-Eosin, and evaluated under light microscopy.

For statistical analysis, conventional analyses of variance (ANOVA) and ANOVA for repeated measures with Tukey as a post-hock test were used (SigmaStat 3.0-Systat Software Inc., San Jose, USA). Occasional correlation between aqueous humor levels of total protein and $\mathrm{PGE}_{2}$ was assessed by Person's correlation test, with 
the level of significance set at $5 \%(\mathrm{P}=0.05)$. Results were expressed as mean and standard error of mean $( \pm$ SEM $)$.

\section{RESULTS}

Significative increased values of protein were observed at M1, in comparison to M0 $(\mathrm{P}<0.001)$. However, after the second paracentesis (M1), values of protein did not significantly change between groups $(\mathrm{P}=0.745)$. Results are summarized in the Table 1 and Figure 1.
Regarding the aqueous humor concentration of prostaglandin $\mathrm{E}_{2}\left(\mathrm{PGE}_{2}\right)$, all samples evaluated at M0 measured below the limit of the assay $(15.00 \mathrm{pg} / \mathrm{mL})$. Significative increased values of $\mathrm{PGE}_{2}$ were observed at M1 $(\mathrm{P}<0.001)$. Results are summarized in the Table 2 and Figure 2.

Protein and $\mathrm{PGE}_{2}$ levels correlated in GI $\left(\mathrm{r}^{2}=0.61 ; \quad \mathrm{P}=0.012\right)$ and in GIII $\left(\mathrm{r}^{2}=0.44\right.$; $\mathrm{P}=0.049)$, whereas the control group $\left(\mathrm{r}^{2}=0.27\right.$; $\mathrm{P}=0.123)$ and the GIII $\left(\mathrm{r}^{2}=0.1442 ; \mathrm{P}=0.3135\right)$ did not show correlation. In animals of the GII, only mild to moderate acute inflammation and hemorrhage were seen (Figure 1).

Table 1. Mean $( \pm$ SEM) values of aqueous humor total protein $(\mathrm{mg} / \mathrm{dL})$, in all studied groups, at moments 0 and 1

\begin{tabular}{lcccc}
\hline & GI & GII & GIII & Control \\
\hline Moment 0 & $14.61 \pm 1.65$ & $11.37 \pm 2.28$ & $14.76 \pm 2.11$ & $10.25 \pm 2.35$ \\
Moment 1 & $218.31 \pm 63.14$ & $295.00 \pm 76.17$ & $176.43 \pm 73.56$ & $314.32 \pm 62.06$ \\
\hline P Value & $0.001^{*}$ & $0.001^{*}$ & $0.001^{*}$ & $0.001^{*}$ \\
\hline
\end{tabular}

*Different from M0 by Tukey's test. GI: subcutaneous route, GII: subconjunctival route, GIII: topical route.

Table 2. Mean $\left( \pm\right.$ SEM) values of aqueous humor Prostaglandin $E_{2}(\mathrm{pg} / \mathrm{mL})$, in all studied groups, at moments 0 and 1

\begin{tabular}{lcccc}
\hline & GI & GII & GIII & Controle \\
\hline Moment 0 & 15.00 & 15.00 & 15.00 & 15.00 \\
Moment 1 & $911.29 \pm 88.70$ & $775.80 \pm 224.19$ & $807.07 \pm 192.92$ & $814.05 \pm 185.95$ \\
\hline P value & $0.001^{*}$ & $0.001^{*}$ & $0.001^{*}$ & $0.001^{*}$
\end{tabular}

*Different from M0 by Tukey's test. GI: subcutaneous route, GII: subconjunctival route, GIII: topical route.

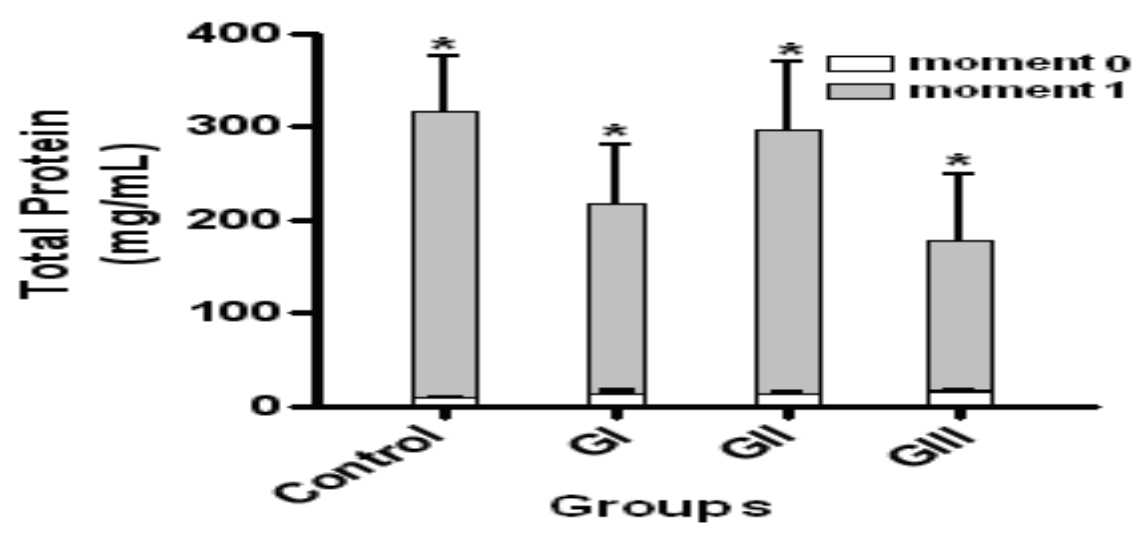

Figure 1. Mean $( \pm$ SEM) values of aqueous humor total protein $(\mathrm{mg} / \mathrm{dL})$ of dogs from control, GI (subcutaneous route), GII (subconjunctival route), and GIII (topical route) groups.

*Different from M0 by Tukey’s test $(\mathrm{P}<0,001)$. 


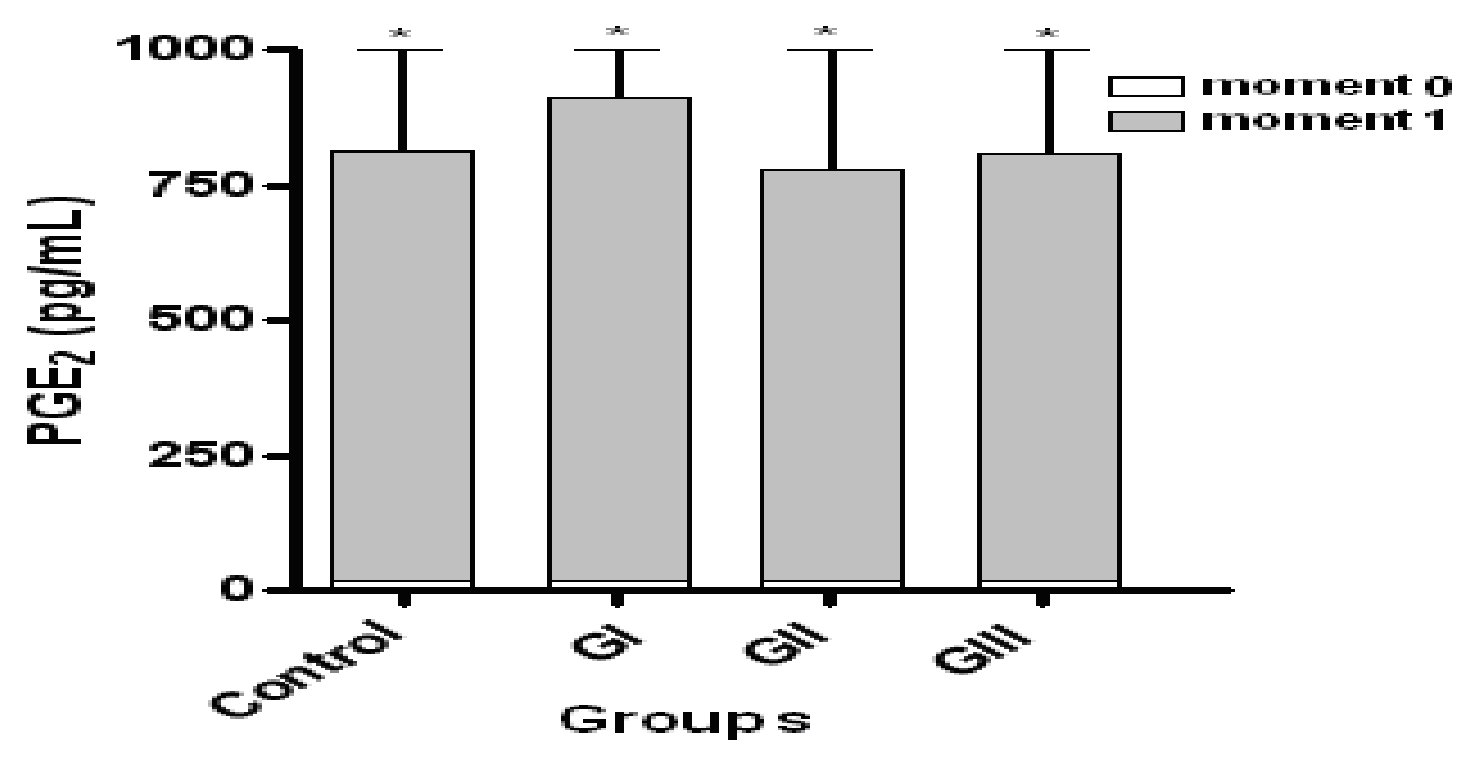

Figure 2. Mean $( \pm \mathrm{SEM})$ values of aqueous humor Prostaglandin $\mathrm{E}_{2}\left(\mathrm{PGE}_{2}\right)(\mathrm{pg} / \mathrm{mL})$ of dogs from control, GI (subcutaneous route), GII (subconjunctival route), and GIII (topical route) groups.

*Different from M0 by Tukey’s test $(\mathrm{P}<0.001)$.
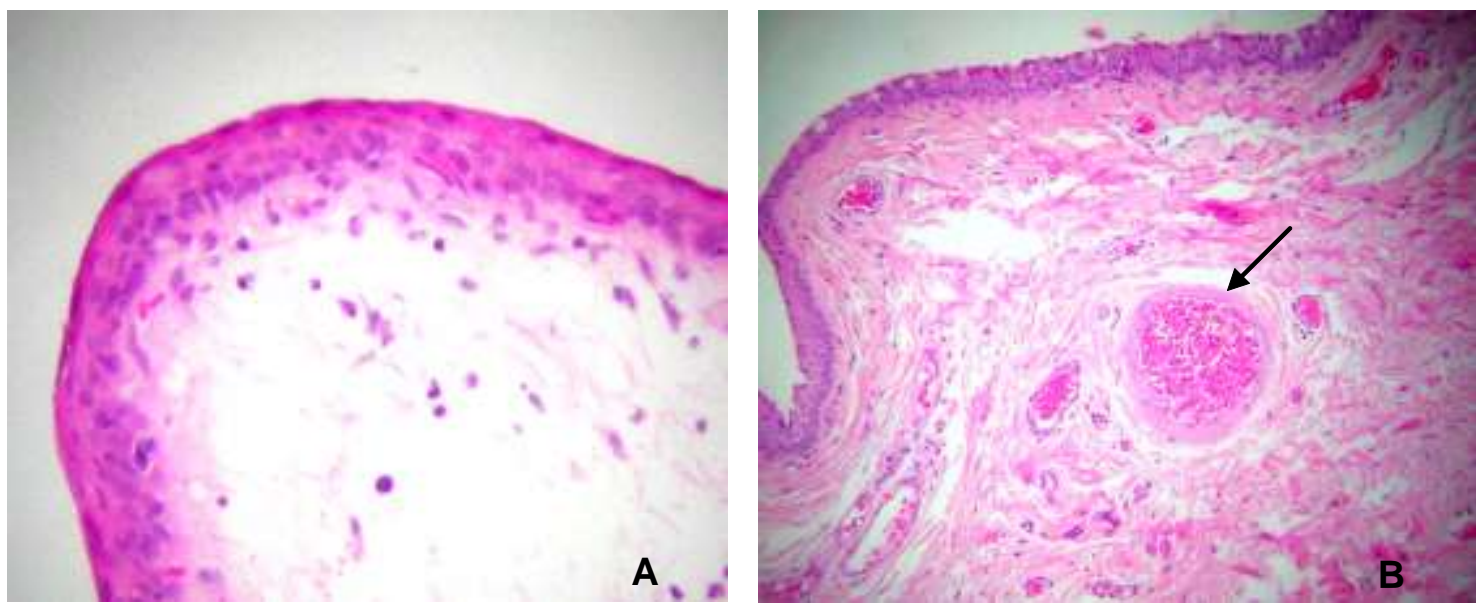

Figure 3. (A) Photomicrograph of the bulbar conjunctiva of a dog of the GII group showing moderate subepithelial edema and mild mixed inflammatory content (Hematoxilin-Eosin, 40X). (B) Photomicrograph of the bulbar conjunctiva of an animal of the GII group. Note the vascular congestion (arrow) (HE - 20X).

\section{DISCUSSION}

It was aimed to study the effects of carprofen administered by different routes after experimentally induced-uveitis in dogs, once good results were obtained with this agent in other tissues (Giuliano, 2004) and because of its safety, as compared with other nonselective cyclooxygenase-2 NSAIDs (Luna et al., 2007).
Even though a significant difference has not been achieved $(\mathrm{P}=0.084)$, all animals treated by the subcutaneous route showed a decrease of $30 \%$ in aqueous humor protein concentration in comparison with the animals of the control group. Similar results were seen after experimental paracentesis in dogs that orally received carprofen (Gilmour and Kennard, 2004). 
These findings are different from those reported by Krohne et al. (1998b), in which animals that orally received carprofen showed a $68 \%$ reduction in protein concentration in aqueous humor. Differences in the protein values seen herein and in the study reported by Krohne et al. (1998b) should be considered, once the protocols adopted for blood-aqueous barrier breakdown were not the same. Those authors used topical $2 \%$ pilocarpine, and the method adopted to quantify the protein concentration in aqueous humor was the laser flaremetry.

Different physiopathological events may result from paracentesis and pilocarpine instillation. Paracentesis may directly stimulate prostaglandin formation by traumatizing the iris and ciliary body, by causing sudden decrease in anterior chamber pressure, or via sheer forces applied to these tissues when aqueous humor is aspirated (Ward, 1996). In contrast, 2\% pilocarpine may cause inflammation of the anterior uveal tract, secondary to neuropeptide release into the aqueous humor, that resulted from trigeminal antidromic stimulation (Krohne et al., 1998a). It was decided to use the paracentesis model, once it better mimics the events that occur during intraocular surgeries (Gelatt and Gelatt, 2001).

Subconjunctival route was one of the focuses of this study because it has advantages in establishing a greater intraocular concentration of the drug that is possible only when frequent topical applications are used, in addition to its reduced costs (Giuliano, 2004). Subconjunctival route showed the lesser efficient route to inhibit the protein influx into the anterior chamber $(6.14 \%)$ when compared with the other treated groups. Similar results were reported when flunixin melgumine was subconjunctivally used in dogs (Galera, 2002).

A previous study reported that higher intraocular concentrations in the anterior segment of the eye were achieved by this route in comparison to the systemic route (Ghate et al., 2007). It may be admitted, that due to the interval adopted between each aqueoucentesis, desirable indexes of the drug could not be able to reach the anterior chamber, like reported by Galera (2002)
Pharmacokinetic data of subconjunctival carprofen administration were not established yet. However, time between drug administration and the second aqueoucentesis was conceived according to pharmacokinetic parameters described when the drug is used by the subcutaneous route, particularly when the higher plasmatic peak is achieved, which occurs in an average of two and half hours followed administration (Clark et al., 2003). When administered by the subconjunctival route, drugs reach the anterior chamber and the vitreous chamber, preferably at equatorial region of the eye, where the scleral thickness is more tenuous (Gilger et al., 2005). Furthermore, hematogenous absorption occurs by subconjunctival vessels, contributing to fractions of the drug reach the systemic circulation and penetrate the eye (Ghate et al., 2007). Studies regarding the pharmacokinetic of drugs in the aqueous humor are quite complexes, once repeated collections are able to modify the aqueous composition, resulting in qualitative alterations of this fluid (Roze et al., 1996).

Recently, Ghate et al. (2007) reported that increased volumes of sodium fluorescein delivered to the eye by different periocular routes have a larger role in transcleral drug delivering than this concentration itself; thus, the inefficacy of carprofen in blocking the anterior uveal tract inflammation may also be explained by the low dose used in this study $(0.2 \mathrm{~mL})$. The high viscosity of the agent hindered that higher volumes could be injected into the subconjunctival space.

Topical route is preferable for the management of uveitis, once it is simple to use and provides desirable intraocular drug concentration. In addition, this route is advantageous once lesser side effects are elicited (Holmemberg and Maggs, 2004; Giuliano, 2004). The severity of inflammation dictates the frequency in which anti-inflammatories should be instilled (Holmemberg and Maggs, 2004; Giuliano, 2004). Factors affecting bioavailability of NSAIDs by the topical route include corneal penetrability, corneal stromal metabolism, and corneal stromal protein binding (Ward, 1996). Particle size may be the most important formulation in determining the bioavailability of the active molecule suspension (Roberts and Nelson, 2007). 
Topical route was tested herein considering that NSAIDs, in general, show similar or even a stronger effect than corticosteroids when used by that route (Krohne et al., 1998a; Andrade et al., 2003). Nonsteroidal antiinflammatory drugs suppress the protein influx to aqueous humor, after one hour and a half, whereas corticosteroids may need six hours after administration to show action by inhibitory effects on expression of the messenger RNAencoding cyclooxygenases-related protein (Hayasaka et al., 2003; Abe et al., 2004). The reduction of only $44 \%$ in protein levels, contrasts the observations of a previous study, which proved that topical flurbiprofen, diclofenac, and suprofen were effective in preventing blood-aqueous barrier disruption after paracentesis in dogs (Ward, 1996).

Once prostaglandins, notably prostaglandin $E_{2}$, act as the major chemical mediator involved in the pathogenesis of anterior uveitis, this research was carried out to study it. At the first moment, prostaglandin $\mathrm{E}_{2}$ concentration was below the limit of the commercial assay $(15.00 \mathrm{pg} / \mathrm{mL})$, in accordance with Gilmour and Lehenbauer (2006). At the second moment, the average of prostaglandin $E_{2}$ found in the control group was $827.76 \mathrm{pg} / \mathrm{mL}$, differing from Gilmour and Lehenbauer (2006) findings, in which dogs that composed the control group achieved an average of $194.17 \mathrm{pg} / \mathrm{mL}$ of prostaglandin $\mathrm{E}_{2}$ in the aqueous humor. Furthermore, in contrast to the present results, dogs treated with oral tepoxalin (NSAID) showed values significative reduced in comparison with controls (Gilmour and Lehenbauer, 2006). Similarly, inhibition of prostaglandin $E_{2}$ levels were noted in dogs treated with carprofen by the same route (Pinard et al., 2006).

Despite Gilmour and Lehenbauer (2006) and Pinard et al. (2006) have used the same methods used herein, for both induction and quantification of the uveitis, those studies evaluated prostaglandin $E_{2}$ levels one hour after the first aqueoucentesis, differently from the five hours adopted in the present study. Considering that the uveal tract has low amounts of the dehydrogenase-15 PG, which is responsible for the inactivation of prostaglandin $\mathrm{E}_{2}$, and also because its activity is decreased in cases of uveitis, these may explain the exacerbated concentration of prostaglandin $\mathrm{E}_{2}$ at the second moment (Collins and Moore, 1999). In addition, the NSAID (tepoxalin) used in that study was administered one hour before paracentesis (Gilmour and Lehenbauer, 2006). Hayasaka et al. (2003) and Abe et al. (2004) demonstrated that topical or intravenous administration of nonsteroidal antiinflammatory drugs are able to suppress the protein influx to aqueous humor, only when used one hour and a half before the blood-aqueous barrier breakdown.

The results also differ from those of Millichamp et al. (1991), which reported that flunixin melgumine was capable to inhibit prostaglandin $\mathrm{E}_{2}$ synthesis in the aqueous humor of dogs, followed one hour of its intravenous administration. However, one may consider that the authors used indirect immunofluorescence to detect prostaglandin $\mathrm{E}_{2}$ in the aqueous humor (Millichamp et al., 1991).

A positive correlation was found only for the animals that subcutaneously and topically received carprofen. Such findings were note observed when dogs orally received tepoxalin (Gilmour and Lehenbauer, 2006).

In the animals that received the agent by the subconjunctival route, acute exudative inflammation and hemorrhage could be seen, which could be attributed to trauma elicited by the injection itself. Subconjunctival plaques were not noted, as once referred by Galera (2002) in a study in which flunixin melgumine was evaluated by the same route.

Despite carprofen was proved to be safe by any of the tested routes, the agent was unable to inhibit the synthesis of $\mathrm{PGE}_{2}$ and the protein influx to the anterior chamber, when administered after paracentesis induced-uveitis in dogs. However, the reduction of $44 \%$ (topical) in protein levels, suggests that carprofen can be used, topically, as an adjuvant to control uveitis in dogs. 


\section{REFERENCES}

ANDRADE, A.L; COSTA, T.A.C.; CIARLLINI, P.C. et al. Uso da flunixina meglumina tópica no tratamento de uveítes em cães. Arq. Bras. Med. Vet. Zootec., v.55, 2003.

ABE, T.; HAYASAKA, Y.; ZHANG, X. et al. Effects of intravenous administration of FR122047 (a selective cyclooxigenase 1 inhibitor) and FR188582 (a selective cyclooxigenase 2 inhibitor) on prostaglandin E2 - induced aqueous flare elevation in pigmented rabbits. Ophathalmic Res., v.36, p.321-326, 2004.

BRIDEAU, C.; VAN STADEN, C.; CHAN, C. In vitro effects of cyclooxygenase inhibitors in whole blood of horses, dogs, and cats. Am. J. Vet. Res., v.62, p.1755-1760, 2001.

CLARK, T.P.; CHIEFFO, C.; HUHN, J.C. et al. The steady-state pharmacokinetics and bioequivalence of carprofen administered orally and subcutaneously in dogs. J. Vet. Pharmacol. Ther., v.26, p.183-192, 2003.

COLLINS, B.K.; MOORE, C.P. Diseases and surgery of the canine uvea. In: GEATT, K.N. Veterinary Ophthalmology. 3.ed. Philadelphia: Lippincott Williams \& Wilkins, 1999. p.755795.

DIZIEZYC, J.; MILLICHAMP, N.J.; KELLER, C. et al. Effects of prostaglandin $F_{2 \alpha}$ and leucotriene $\mathrm{D}_{4}$ on pupil size, intraocular pressure, and blood-aqueous barrier in dogs. Am. J. Vet. Res., v.53, p.1302-1304, 1992.

GALERA, P.D. Estudo do flunixin meglumine (Banamine $^{\circledR}$ ) após aplicação subconjuntival, em cães. 2002. 57f. Tese (Doutorado em Cirurgia Veterinária) - Faculdade de Ciências Agrárias e Veterinárias - Universidade Estadual Paulista, Jaboticabal.

GELATT, K.N.; GELATT, J.P. Surgical procedures of the anterior chamber and anterior uvea. In:__Small animal ophthalmic surgery. Oxford: Butterworth \& Heinemann, 2001. p.219-243.

GHATE, D.; BROOKS, W.; McCAREY, B.E. et al. Pharmacokinetics of intraocular drug delivery by periocular injections using ocular fluorophotometry. Invest. Ophthalmol. Vis. Sci., v.48, p.2230-2237, 2007.
GILGER, B.C.; REEVES, K.A.; SALMON, J.H. Ocular parameters related to drug delivery in the canine and equine eye: aqueous and vitreous humor volume and scleral surface area and thickness. Vet. Ophthalmol., v.8, p.265-269, 2005.

GILMOUR, M.A.; LEHENBAUER, T.W. Effects of tepoxalin in reducing intraocular inflammation in the dog. In: ANNUAL MEETING OF THE AMERICAN COLLEGE OF VETERINARIAN OPHTHALMOLOGISTS, 2006, San Antonio, TX, USA. Vet. Ophthalmol., v.9, p.414-425, 2006.

GILMOUR, M.; KENNARD, G. Effects of oral meloxicam, deracoxib, tepoxalin and carprofen in reducing intraocular inflammation in the dog. In: ANNUAL MEETING OF THE AMERICAN COLLEGE OF VETERINARIAN OPHTHALMOLOGISTS, 2004, Washington, DC, USA. Vet. Ophthalmol., v.7, p.437-453, 2004.

GIULIANO, E.A. Nonesteroidal antiinflamatory drugs in Vet. Ophthalmol. Vet. Clin. N. Am.: Small Anim. Pract., v.34, p.707-723, 2004.

GUM, G.G.; GELATT, K.N.; OFRI, R. Phisiology of the eye. In: GELATT, K.N. Veterinary Ophthalmology. 3.ed. Philadelphia: Lippincott Williams \& Wilkins, 1999. p.151182.

HAYASAKA, Y.; HAYASAKA, S.; ZHANG, $X . Y$. et al. Effects of topical corticosteroids and nonsteroidal anti-infllammatory drugs on prostaglandin $\mathrm{E}_{2}$ - induced aqueous flare in pigmented rabbits. Ophthalmic Res., v.35, p.341-344, 2003.

HOLMEMBERG, B.J.; MAGGS, D.J. The use of corticosteroids to treat ocular inflammation. Vet. Clin. N. Am.: Small Anim. Pract., v.34, p.693-705, 2004.

KRONE, G.S.; GIONFRIDDO, J.; MORRISON, E. Inhibition of pilocarpineinduced aqueous humor flare, hypotony, and miosis by topical administration of antiinflamatory and anestesic drugs to dogs. Am. J. Vet. Res., v.59, p.482-488, 1998a. 
KRONE, G.S.; BLAIR, M.J.; BINGAMAN, D. et al. Carprofen inhibition of flare in the dog measured by laser flare photometry. Vet. Ophthalmol., v.1, p.81-84, 1998b.

LUNA, S.P.; BASÍLIO, A.C.; STEAGALL, P.V.M. et al. Evaluation of adverse effects of long-term oral administration of carprofen, etodolac, flunixin meglumine, ketoprofen, and meloxicam in dogs. Am. J. Vet. Res., v.68, p.258-264, 2007.

MASSA, K.L.; GILGER, B.C.; MILLER, T.L. et al. Causes of uveitis in dogs: 102 cases (19892000). Vet. Ophthalmol., v.5, p.93-98, 2002.

MILLICHAMP, N.J.; DIZIEZIC, N.; ROHDE, B.H. et al. Acute effects of anti-inflamatory drugs on neodymium: yttrium aluminium garnet laser-induced uveitis in dogs. Am. J. Vet. Res., v.52, p.1279-1284, 1991.

PINARD, M.M.; MARTEL-PELLETIER, J.; GAUVIN, D. et al. Effect of carprofen on aqueous humor levels of $\mathrm{PGE}_{2}$, NOX and TNF$\alpha$ in an experimental canine uveitis model In: ANNUAL MEETING OF THE AMERICAN COLLEGE OF VETERINARIAN OPHTHALMOLOGISTS, 2006, San Antonio, TX, USA. Vet. Ophthalmol., v.9, p.414-425, 2006.

ROBERTS, C.W.; NELSON, P.L. Comparative analysis of prednisolona suspensions. J. Ocular Pharmacol. Ther., v.23, p.182-187, 2007.
ROZE， M.; THOMAS, E.; DAVOT, J.L Tolfenamic acid in the control of ocular inflammation in dog: pharmacokinetics and clinical results obtained in an experimental model. J. Small Anim. Pract., v.37, p.371-375, 1996.

STREPPA, H.K; JONES, C.J.; BUDSBERG, S.C. Cliclooxygenase selectivity of nonsteroidal anti-inflamatory drugs in canine blood. Am. J. Vet. Res., v.63, p.91-94, 2002.

van der WOERDT, A. Management of intraocular inflammatory disease. Clin. Tech. Small Anim. Pract., v.16, p.58-61, 2001.

WARD, D.A. Comparative efficacy of topically applied flurbiprofen, diclofenac, tolmetin, and suprofen for the treatment of experimentally induced blood aqueous barrier disruption in dogs. Am. J. Vet. Res., v.57, p.875-878, 1996.

WARD, D.A.; FERGUNSON, D.C.; KASWAN, R.L. et al. Fluorophotometric evaluation of blood-aqueous barrier disruption in dogs. Am. J. Vet. Res., v.52, p.1433-1437, 1991.

WARD, D.A.; FERGUNSON, D.C.; KASWAN, R.L. et al. Leukotrienes and sensory innervation in blood-aqueous barrier disruption in the dog. $J$. Ocular Pharmacol., v.8, p.69-76, 1992. 